\title{
Üroloji Hastasında Ă̆rı Yönetimi: Güncel Yaklaşımlar ve Kanıta Dayalı Uygulamalar
}

\author{
Pain Management in Urology Patient: Current Approaches and Evidence-Based \\ Practices
}

\author{
Didem KANDEMIR' ${ }^{1}$, Ayfer ÖZBAŞ², Nevin KANAN ${ }^{3}$
}

İletişim/ Correspondence: Didem KANDEMIR Adres/ Address: İstanbul Üniversitesi Florence Nightingale Hemşirelik Fakültesi, Cerrahi Hastalıkları Hemşireliği AD., Abide-i Hürriyet Cad. 34381, Şişli/ İstanbul Tel: 021244000 00/27042 Fax: 021222449 90 E-mail: didem_ztrk@hotmail.com

\section{$\ddot{O} Z$}

Ăgrl; vücudun herhangi bir yerinden kaynaklanan olası bir doku hasarı ile birlikte seyreden ve bireyin geçmişteki tüm deneyimlerini kapsayan, hoş olmayan, emosyonel ve sensoriyal bir deneyimdir. Ürolojik ağrının şiddeti, genellikle ani başlangıciyla ilişkilidir. Bu nedenle, üriner sisteme bağll görülen lokal ve yanslyan ağrı yönetimi önemlidir. Bu derleme, ameliyata, interstisyel sistit/ ağrll mesane sendromu, üretral ağrl sendromu, prostat ağrl sendromu, skrotal ă̆rl sendromu ve penil ă̆rı sendromunu içeren ürolojik ağrı sendromlarına ve taş hastalı̆̆ına bă̆l olarak gelişen şiddetli ă̆rı ile kendini gösteren, sık karşılaşılan ve hastanın yaşam kalitesini olumsuz yönde etkileyen ürolojik ağrlların yönetiminde, güncel yaklaşımları ve kanıta dayalı uygulamaları Avrupa Üroloji Derneği'nin (European Association of Urology-2014) yayınladı̆̆ rehberler ışı̆̆ında tartışmak amacıyla, ele alındı. A $\breve{g r l}$ yönetimine yönelik sürekli elde edilen yeni bilgiler, sağlık profesyonellerinin hasta için en iyi ve en doğru olan yöntemi seçebilmesini gerektirmektedir. Kanıta dayalı klinik uygulama rehberlerinin izlemi bu amaca ulaşmada anahtar rol oynamaktadır.

Anahtar Kelimeler: Ăgrı yönetimi, kanıta dayalı uygulamalar, hemşirenin rolü, üroloji.

\section{ABSTRACT}

Pain is an unpleasant, emotional and sensory experience arising from any part of the body, associated with a possible tissue damage, and covers all the past experiences of the individual. The severity of urological pain is often associated with its sudden onset. Therefore, local and referred pain management seen associated with the urinary tract is important. This review was studied to discuss the actual approaches and evidence-based practices in the light of the guidelines published by the European Association of Urology (EAU, 2014) in management of urological pain, which indicates itself with severe pain that emerges secondary to surgery, to urological pain syndromes including interstitial cystitis/painful bladder syndrome, urethral pain syndrome, prostatic pain syndrome, scrotal pain syndrome and penile pain syndrome and to stone disease; which is common and negatively affecting the patient's quality of life. Continuous new information obtained for pain management requires for the healthcare professionals to choose the best and most accurate method for patients. Monitoring of the evidence-based clinical practice guidelines plays a key role in achieving this goal.

Keywords: Pain management, evidence-based practice, nurse's role, urology.

23. Ulusal Üroloji Kongresi ve 6. Ulusal Üroloji Hemşireliği Kongresi’nde panel/ konferans bildirisi olarak sunulmuştur (16 - 19 Ekim 2014, Antalya/ TÜRKIYE), 'Arş. Gör. İstanbul Üniversitesi Florence Nightingale Hemşirelik Fakültesi, İstanbul/ TURKEY, ${ }^{2}$ Doç. Dr. İstanbul Üniversitesi Florence Nightingale Hemşirelik Fakültesi, İstanbul/ TURKEY, ${ }^{3}$ Prof. Dr. İstanbul Üniversitesi Florence Nightingale Hemşirelik Fakültesi İstanbul/ TURKEY

Yazının gönderilme tarihi: 19.01.2015

Yazının basım için kabul tarihi: 30.09 .2016

doi: $10.17672 /$ fnhd.56731 


\section{GİRIŞ}

Ağrı; duyusal, emosyonel ve davranışsal faktörlerden etkilenen karmaşık bir deneyimdir. Ağrının temel öğeleri ağrının oluşumu, ağrının algılanması, acı çekme ve ağrıya bağlı davranışlar olarak sıralanabilir. Uluslararası Ağrı Araştırmaları Birliği’nin (International Association for the Study of Pain-IASP) tan1mına göre ağrı; vücudun herhangi bir yerinden kaynaklanan olası bir doku hasarı ile birlikte seyreden ve bireyin geçmişteki tüm deneyimlerini kapsayan, hoş olmayan, emosyonel ve sensoriyal bir deneyimdir (Atan ve Tuncel 2013).

Ürolojik ağrının şiddeti, genellikle ani başlangıcıyla ilişkilidir. $\mathrm{Bu}$ nedenle, üriner sisteme bağlı görülen lokal ve yansıyan ağrı yönetimi önemlidir. Daha sık görülen lokal ağrı, genellikle kronikleşen hastalıkların bir belirtisi olup, hasta organ ya da çevresinde hissedilir. Örneğin; böbreklerle ilgili hastalıklarda lokal olarak kosto-vertebral açıda ve lomber bölgede ağrı vardır. Çoğunlukla akut hastalıkların bir belirtisi olan yansıyan ağrılar ise, hastalıklı organlardan kaynaklanmakla birlikte, belirli bir uzaklıkta hissedilir. Örneğin; üst üreterde taşa bağlı olarak gelişen üreter kolik ağr1S1, aynı taraf testiste şiddetli ağrı olarak yansır (Erdil 2008; Karaca ve Yeşiltepe-Kaçar 2013).

$\mathrm{Bu}$ derleme, ameliyata, kronik pelvik ağrı sendromuna ve taş hastalığına bağlı olarak gelişen şiddetli ağrı ile kendini gösteren, sık karşılaşılan ve hastanın yaşam kalitesini olumsuz yönde etkileyen ürolojik ağrıların yönetiminde, güncel yaklaşımları ve kanıta dayalı uygulamaları Avrupa Üroloji Derneği’nin (European Association of Urology-2014) yayınladığ 1şığında tartışmak amacıyla ele alındı.

\section{ÜRINER SİSTEM AMELIYATI SONRASI AĞRI YÖNETIMI}

Cerrahi girişime bağlı oluşan bölgesel doku hasarı, ilk olarak lokal inflamatuar ve sistemik olayların oluşumuna neden olur. Lokal inflamatuar yanıt sonucu olarak hem hasarlı dokudan hem de inflamatuar hücrelerden bazı maddeler (potasyum, sitokinler, hista- min, serotonin, prostaglandin ve lökotrienler) hücre dışına çıkar. Bu maddeler nosiseptörlerin duyarlılığı$\mathrm{n} 1$ arttırır. Bunun sonucunda da travma alanında ağr1lı uyarana daha fazla yanıt oluşur ve buna birincil hiperaljezi adı verilir. Bu olay, insizyona bağlı olarak ortaya çıkar. Bu arada uyaran, spinal korda ve çevredeki diğer nosiseptörlere de taşınır. Komşu dokularda oluşan duyarlılık artışına ise ikincil hiperaljezi denir. Bu durum, çevredeki hasarsız dokularda oluşan duyarlılık artışı ile ilişkilidir (Atan ve Tuncel 2013; Frizelle 2006).

Cerrahi sonrasında meydana gelen ağrılar, inflamatuar ve nöropatik kökenlidir. İnflamatuar ağrı, insizyon ile ilişkili iken; nöropatik ağrı, sinir hasarına bağlı olarak gelişir (Atan ve Tuncel 2013).

Ameliyat sonrası ağrı yönetimine ilişkin öneriler Tablo 1'de yer almaktadır.

Tablo 1. Ameliyat Sonrası Ağrı Yönetimine İlişkin Öneriler

\begin{tabular}{|l|c|}
\hline Öneriler & $\begin{array}{c}\text { Öneri } \\
\text { Düzeyi }\end{array}$ \\
\hline $\begin{array}{l}\text { Ameliyat öncesi değerlendirme ve hastanın } \\
\text { hazırlanması daha etkili ağrı yönetimi } \\
\text { sağlar. }\end{array}$ & A \\
\hline $\begin{array}{l}\text { Ameliyat sonrası yeterli ağrı değerlendirmesi } \\
\text { etkin ağrı kontrolü sağlar ve komplikasyon } \\
\text { riskini azaltır. }\end{array}$ & B \\
\hline $\begin{array}{l}\text { Nonsteroid anti-inflamatuar ilaçlar } \\
\text { (NSAİİ) genellikle hafif veya orta düzeyde } \\
\text { ameliyatlardan sonra etkilidir. }\end{array}$ & B \\
\hline NSAİ̇, opioid gereksinimini azaltır. & B \\
\hline $\begin{array}{l}\text { Parasetamol, ameliyat sonrası opioid } \\
\text { tüketimini azalttığı için ağrı tedavisinde } \\
\text { önerilir. }\end{array}$ & B \\
\hline $\begin{array}{l}\text { Tek bir tedavi olarak parasetamol yönetimi, } \\
\text { önemli yan etkileri olmadan ameliyat sonrası } \\
\text { hafif ağrıyı azaltmak için önerilir. }\end{array}$ & B \\
\hline $\begin{array}{l}\text { Ameliyat sonrası üstün analjezi sağlaması, } \\
\text { hasta memnuniyetini arttırması ve solunum } \\
\text { sistemine yönelik komplikasyon riskini } \\
\text { azaltması nedeniyle hasta kontrollü analjezi } \\
\text { (HKA) önerilir. }\end{array}$ & A \\
\hline
\end{tabular}




\begin{tabular}{|l|c|}
\hline $\begin{array}{l}\text { Uygun dozda ek ilaçlar uygulanır ve } \\
\text { analjeziklerin etkinliğini arttırmak ve opioide } \\
\text { bağlı yan etkileri azaltmak için bakım izlenir. }\end{array}$ & A \\
\hline $\begin{array}{l}\text { Opioid gereksinimini azaltmak için ameliyat } \\
\text { öncesi veya ameliyat sonrası epidural olarak } \\
\text { klonidin önerilir. }\end{array}$ & A \\
\hline $\begin{array}{l}\text { Gabapentin ağrı şiddetini ve ek analjezik } \\
\text { gereksinimini azaltmak için ameliyattan önce } \\
\text { ve sonra uygulanabilir. }\end{array}$ & A \\
\hline $\begin{array}{l}\text { Epidural analjezi, özellikle hasta kontrollü } \\
\text { epidural analjezi (HKEA), ameliyat sonrası } \\
\text { üstün analjezi sağlar. HKEA, komplikasyon } \\
\text { riskini azaltır, hasta memnuniyetini arttırır. }\end{array}$ & A \\
$\begin{array}{l}\text { Bu nedenle sistemik tekniklere tercih } \\
\text { edilmektedir. }\end{array}$ & \\
\hline
\end{tabular}

Kaynak: Paez-Borda, A., Charnay-Sonnek, F., Fonteyne, V., Papaioannou, E. G. (2014). Guidelines on pain management \& palliative care. European Association of Urology, 34-35, https://uroweb.org/wp-content/uploads/25-Pain-Management LR.pdf (10.08.2014).

(A-Belli başlı önerileri işaret eden ve en az bir randomize deneyi kapsayan, kaliteli ve tutarlı klinik çalışmalara dayalıdır. B-Randomize klinik çalışmalar dışında iyi yürütülmüş klinik çalışmalara dayalıdır. C-Doğrudan uygulanabilir kaliteli klinik çalışmaların yokluğuna karşın önerilmiştir.)

Etkin bir ameliyat sonrası ağrı yönetiminin önemi, genellikle anestezist tarafindan yönetilen, hemşire ve eczacıdan oluşan ameliyat sonrası akut ağrı yönetimi ekiplerinin gelişmesine yol açmıştır. Ekip işbirliğinin, ağrıyı ve analjeziklerin yan etkilerini azalttığ 1 , hasta memnuniyetini arttırdığı, morbidite oranlarını ve hastane maliyetini azalttığı gösterilmiştir (Kanıt düzeyi: 2b). Etkin ağrı kontrolünün, hastanede yatış süresini kısaltabildiği, günübirlik cerrahi sonrası plansız yapılan yatışları azalttı̆̆ 1 saptanmıştır (Kanıt düzeyi: 3) (Paez-Borda, CharnaySonnek, Fonteyne ve Papaioannou 2014).

\section{KRONIK PELVIKK AĞRI SENDROMUNDA AĞRI YÖNETIMI}

Kronik pelvik ağrı, hem erkek hem de kadınlarda görülebilen pelvis ile ilgili yapılarda algılanan kronik veya inatçı ağrı olarak tanımlanmaktadır. Zaman içinde kronik/ kalıcı olarak ifade edilen nosiseptif ağrı durumunda, ağrı en az 6 ay boyunca sürekli veya tekrar- layan olmalıdır. Yani, 6 aylık bir dönemde dismenore gibi döngüsel de olabilir (Engeler ve ark. 2014).

Kronik pelvik ağrı, infeksiyon, kanser vb. kanıtlanmış bir patolojik durum ile görülebileceği gibi, belirgin bir patoloji olmadan da görülebilir. Kronik pelvik ağrının bir alt bölümü olan kronik pelvik ağrı sendromu, genellikle alt üriner sistem, cinsellik, bağırsak veya jinekolojik işlev bozukluğunu düşündüren semptomların yanı sıra olumsuz bilişsel, davranışsal, cinsel veya duygusal sonuçlar ile ilişkili olduğu belirtilmektedir (Engeler ve ark. 2014).

Aşağıdaki sınıflandırma sadece kronik pelvik ağrı sendromu ile ilgilidir. Buna göre ürolojik ağrı sendromlar1,

- İnterstisyel sistit/ Ağrılı mesane sendromu

- Üretral ağr1 sendromu

- Prostat ağr1 sendromu

- Skrotal ağrı sendromu

- Penil ağr1 sendromunu içerir (Engeler ve ark. 2014).

\section{İnterstisyel Sistit/ Ağrılı Mesane Sendromunda Ağrı Yönetimi}

İnterstisyel sistit/ ağr1l mesane sendromu, mesane bölgesinde algılanan kalıcı veya tekrarlayan ağrı, idrar sıklığ1 ve sıkışmanın görüldüğü alt üriner sistemin kronik ve ilerleyici bir hastalığıdır. Sık idrara çıkma, sıkışma, idrar kaçırma, mesane bölgesinde ağrı, gece idrara çıkma interstisyel sistit/ ağrılı mesane sendromunun başlıca semptomları olarak görülmektedir (Engeler ve ark. 2014).

Ağrı, sürekli ya da aralıklarla gelişebilir, tüm pelvik tabana ve sırtın alt bölümlerine yayılabilir. Yaygın olarak suprapubik bölgede hissedilen ağrı, kadınlarda üretra, vajina ya da diğer pelvik bölümlerde, erkeklerde ise peniste, testislerde, skrotumda ve perinede olabilir. Ağrı, mesanede yanma hissi, mesane ya da çevresinde spazm veya batıcı tarzda bir vajinal ağrı şeklinde olabileceği gibi mesanede basınç şeklinde de hissedilebilir (Özbaş ve Altun-Uğraş 2012).

Ağrı kontrolü amaciyla, narkotik ve antikonvülsan ilaçlar kullanılmaktadır (Özbaş ve Altun-Uğraş 2012). Bir 
trisiklik antidepresan olan amitriptilin (Foster ve ark. 2010; Van Ophoven, Pokupic, Heinecke ve Hertle 2004; Van Ophoven ve Hertle 2005) ve antiepileptik bir ajan olan gabapentin (Hansen 2000; Sasaki ve ark. 2001), kronik ağrıları olan interstisyel sistitli hastalarda analjezi oluşturabilmektedirler (Atuğ ve Canoruç 2005).

Hafif esneme egzersizleri, mesane üzerine soğuk ya da sıcak uygulama, 1lık duş alma, semptomları azaltmaya yardımcı olmaktadır. Bu teknikler, daha çok mesane dolduğunda ortaya çıkan hafif ağrısı olan hastalar için uygundur. Ayrica fizik tedavi ve biyolojik geri bildirim spazmı olan hastalarda, pelvik taban kaslarının gevşemesinde kullanılabilir (Chaiken, Blaivas ve Blaivas 1993; Özbaş ve Altun-Uğraş 2012; Parsons ve Koprowski 1991).

Ağrıyı daha da arttıracağından hastaların; çikolata, kahve, çay, alkollü ve asitli içecekler, elma/ elma suyu, turunçgiller (limon, misket limonu, greyfurt, portakal vb.)/ turunçgil suyu, çilek, şeftali, ananas, avokado, muz, yaban mersini, üzüm/ üzüm suyu, kuru üzüm, erik (taze/ kuru), findık, badem, yer ve çam fistığı, mercimek, soğan, domates, baharatll yiyecekler, mayonez, peynir, yoğurt, sığır eti, tavuk ciğeri, çavdar ekmeği, soya sosu, sirke gibi besinleri mümkün olduğunca az tüketmesi önerilmektedir (Özbaş ve Altun-Uğraş 2012).

İnterstisyel sistit/ ağrılı mesane sendromunda ağrı yönetimine ilişkin öneriler Tablo 2'de yer almaktadır.

Tablo 2. İnterstisyel Sistit/ Ağrılı Mesane Sendromunda Ağrı Yönetimine İlişkin Öneriler

\begin{tabular}{|l|c|}
\hline Öneriler & $\begin{array}{c}\text { Öneri } \\
\text { Düzeyi }\end{array}$ \\
\hline $\begin{array}{l}\text { Opioidler, ağrılı mesane sendromunun alevlenme } \\
\text { (flare-ups) evresinde kullanılır. }\end{array}$ & $\mathrm{C}$ \\
\hline $\begin{array}{l}\text { Amitriptilin, ağrılı mesane sendromunun } \\
\text { yönetiminde kullanılır. }\end{array}$ & $\mathrm{A}$ \\
\hline $\begin{array}{l}\text { Ağrısı az olan hastalarda mesane eğitimi } \\
\text { düşünülür. }\end{array}$ & $\mathrm{B}$ \\
\hline $\begin{array}{l}\text { Ağrıyı tetikleyen bazı yiyecek ve içeceklerden } \\
\text { kaçınılır. }\end{array}$ & $\mathrm{C}$ \\
\hline
\end{tabular}

Kaynak: Engeler, D. ve ark. (2014). Guidelines on chronic pelvic pain. European Association of Urology, 44-45, https://uroweb.org/wp-content/uploads/26-Chronic-Pelvic-Pain_LR.pdf (10.08.2014).

\section{Üretral Ağrı Sendromunda Ağrı Yönetimi}

Üretral ağrı sendromu, kanıtlanmış infeksiyon ya da başka bir lokal patoloji yokluğunda üretrada algılanan kronik veya tekrarlayan epizodik ağrı durumudur. Üretral ağrı sendromu, hem erkeklerde hem de kadınlarda görülebilir (Engeler ve ark. 2014).

Üretral ağrı sendromunda ağrı tedavisine yönelik öneriler Tablo 3'te yer almaktadır

Tablo 3. Üretral Ağrı Sendromunda Ağrı Tedavisine Yönelik Öneriler

\begin{tabular}{|l|c|}
\hline Öneriler & $\begin{array}{c}\text { Öneri } \\
\text { Düzeyi }\end{array}$ \\
\hline $\begin{array}{l}\text { Tedaviye, kronik pelvik ağrı sendromuna } \\
\text { yönelik tedavi seçenekleri ile başlanılır. }\end{array}$ & A \\
\hline $\begin{array}{l}\text { Üretral ağrı sendromu olan hastaların } \\
\text { tedavisinde disiplinler arası ve çoklu } \\
\text { (multimodal) yaklaşım önerilir. }\end{array}$ & $\mathrm{B}$ \\
\hline $\begin{array}{l}\text { Hastaların yaşam kalitesini arttırmak için ağrı } \\
\text { ile ilgili psikolojik tedaviye başvurmaları } \\
\text { önerilir. }\end{array}$ & $\mathrm{B}$ \\
\hline
\end{tabular}

Kaynak: Engeler, D. ve ark. (2014). Guidelines on chronic pelvic pain. European Association of Urology, 75-76, https://uroweb.org/wp-content/uploads/26-Chronic-Pelvic-Pain_LR.pdf (10.08.2014).

\section{Prostat Ağrı Sendromunda Ă̆rı Yönetimi}

Prostat ağrı sendromu, 6 ay içinde en az 3 ay prostat bölgesinde algılanan inatçı ve tekrarlayan epizodik ağrı varlığı olarak tanımlanır. Ağn genellikle perine, rektum, penis, testisler ve abdominal bölge gibi prostat dışında diğer pelvik bölgelerde bildirilir. Prostat ağrı sendromu, genellikle alt üriner sistem ve cinsel işlev bozukluğunu düşündüren semptomların yanı sıra olumsuz bilişsel, davranışsal, cinsel veya duygusal sonuçlar ile ilişkili olduğundan söz edilmektedir (Engeler ve ark. 2014).

Ağrı yönetiminde (kanser ağrısı hariç), opioid kullanımının uzun vadeli etkinliğine ilişkin kısıtlı veri olmasına karşın; opioidler, ağrının giderilmesi amacıyla prostat ağrı sendromlu bazı hastalarda kullanılması önerilmektedir. Opioid tedavisi, yaşam kalitesinin düşmesi, bağımlılık, ilaç toleransı ve opioid ilişkili 
hiperanaljezi vb. yan etkilerin ortaya çıkma riskini taşımaktadır. Hemşire, bu yan etkiler açısından hastay1 gözlemlemelidir. Sadece ağrı klinikleri ile işbirliği içinde kullanılmalıdır (Engeler ve ark. 2014).

Fitoterapinin prostat ağrı sendromu olan hastalarda olumlu etkileri bazı çalışmalarla gösterilmiştir (Anothaisintawee ve ark. 2011; Elist 2006; Wagenlehner ve ark. 2009). Wagenlehner ve ark. (2009) tarafindan yapılan randomize kontrollü bir çalışmada, polen ekstresi olan Cernilton'un inflamatuar prostat ağrı sendromu olan hastalarda 12 haftalık dönemde klinik olarak ağrı düzeyinde anlamlı olarak azaldığı saptanmıştır ( $\mathrm{p}=0.0086)$. Anothaisintawee ve ark. (2011) tarafından 3'ü fitoterapi ile ilgili olmak üzere 23 çalışmanın incelendiği sistematik derleme ve meta-analiz çalışmasında, kontrol grubuna göre fitoterapi uygulanan hastalarda, ağrı düzeyinin anlamlı olarak daha düşük olduğu bulunmuştur.

Prostat ağrı sendromunda ağrı yönetimine ilişkin öneriler Tablo 4'te yer almaktadır.

Tablo 4. Prostat Ağrı Sendromunda Ağrı Yönetimine İlişkin Öneriler

\begin{tabular}{|l|c|}
\hline Öneriler & $\begin{array}{c}\text { Öneri } \\
\text { Düzeyi }\end{array}$ \\
\hline $\begin{array}{l}\text { Alfa-blokerler, prostat ağrı sendromu (1 } \\
\text { yıldan az süredir) olan hastalar için önerilir. }\end{array}$ & $\mathrm{A}$ \\
\hline $\begin{array}{l}\text { NSAİİ, prostat ağrı sendromunda önerilir; } \\
\text { ancak uzun dönem yan etkileri dikkate } \\
\text { alınmalıdır. }\end{array}$ & $\mathrm{B}$ \\
\hline $\begin{array}{l}\text { Fitoterapi, prostat ağrı sendromu olan } \\
\text { hastalarda kullanılabilir. }\end{array}$ & $\mathrm{B}$ \\
\hline Psikolojik tedavide ağrıya odaklanılır. & $\mathrm{B}$ \\
\hline
\end{tabular}

Kaynak: Engeler, D. ve ark. (2014). Guidelines on chronic pelvic pain. European Association of Urology, 29-30, https:// uroweb.org/wp-content/uploads/26-Chronic-Pelvic-Pain LR.pdf (10.08.2014).

\section{Skrotal Ağrı Sendromunda Ağrı Yönetimi}

Skrotal ağrı sendromu skrotum organları içinde lokalize, kalıcı veya tekrarlayan epizodik ağrı varlığıdır ve idrar yolu veya cinsel işlev bozukluğunu düşündüren semptomlar ile ilişkili olabilir. Kanıtlanmış infeksiyon ya da başka bir patoloji yoktur. Skrotal ağrı sendromu, ağrı bölgesi açıkça testis veya epididim olmadığında kullanılan genel bir terimdir. Ağrı skrotum cildinde değil, idiyopatik göğüs ağrısına benzer şekilde skrotum içinde hissedilir (Engeler ve ark. 2014).

Skrotal ağrı sendromunda ağrı yönetimine ilişkin öneriler Tablo 5'te yer almaktadir.

Tablo 5. Skrotal Ağrı Sendromunda Ağrı Yönetimine İlişkin Öneriler

\begin{tabular}{|l|c|}
\hline Öneriler & $\begin{array}{c}\text { Öneri } \\
\text { Düzeyi }\end{array}$ \\
\hline $\begin{array}{l}\text { Tedaviye, kronik pelvik ağrı sendromuna } \\
\text { yönelik tedavi seçenekleri ile başlanır. }\end{array}$ & $\mathrm{A}$ \\
\hline $\begin{array}{l}\text { Vazektomi planlanan hastalara vazektomi } \\
\text { sonrası ağrı riskine ilişkin bilgi verilir. }\end{array}$ & $\mathrm{A}$ \\
\hline $\begin{array}{l}\text { Skrotal ağrı riskini azaltmak için laparoskopik } \\
\text { yerine açık inguinal herni onarımı önerilir. }\end{array}$ & $\mathrm{A}$ \\
\hline $\begin{array}{l}\text { Bu inguinal herni onarımı sırasında spermatik } \\
\text { korddaki tüm sinirlerin belirlenmesi önerilir. }\end{array}$ & $\mathrm{A}$ \\
\hline $\begin{array}{l}\text { Cerrahi olarak tedavi edilen hastalara } \\
\text { spermatik kord mikrocerrahi olarak sinirlerin } \\
\text { bloke edilmesi (denervasyon) önerilir. }\end{array}$ & $\mathrm{A}$ \\
\hline $\begin{array}{l}\text { Sinirlerin bloke edilmesi yararlı olmayan } \\
\text { hastalara epididimektomi önerilir. }\end{array}$ & $\mathrm{B}$ \\
\hline $\begin{array}{l}\text { Ağrı yönetiminin değerlendirilmesi } \\
\text { dahil olmak üzere uygulanan diğer tüm } \\
\text { tedavi yöntemleri başarısız olana kadar } \\
\text { orşiektominin yapılmaması önerilir. }\end{array}$ & $\mathrm{C}$ \\
\hline
\end{tabular}

Kaynak: Engeler, D. ve ark. (2014). Guidelines on chronic pelvic pain. European Association of Urology, 71-72, https://uroweb.org/wp-content/uploads/26-Chronic-Pelvic-Pain_LR.pdf (10.08.2014).

\section{RENAL KOLİKTE AĞRI YÖNETIMI}

Renal kolik, sıklıkla böbrek taş hastalığına bağlı olarak gelişen, şiddetli ağr1 ile kendini gösteren ürolojik acil bir durumdur. Ağrı tipik olarak kosto-vertebral açıda künt, sürekli ve kıvrandırıcı şekilde hissedilir (Ay ve ark. 2014; Çakıroğlu ve ark. 2013).

Renal kolik ağrısı, sıklıkla üriner sistem taşları nedeniyle meydana gelmektedir. Taşlar, idrar akışını engelleyerek idrar yolunun herhangi bir bölümünü etkileyebilir. Ürolitiazis (idrar yolu içinde taşların gelişmesi) idrar akışının engellenmesinin en sık nedenidir (Burke, Mohn-Brown ve Eby 2011). Üreterin üst bölümlerinde 
olan taşlarda ağrılar genellikle kasıklara, distal üreterdekilerde ise testislere ve labialara doğru yayılmaktadır. Taşa bağlı akut obstrüksiyon sonucu oluşan kolik ağrı süreklidir, pozisyonla değişmez, ağrı şiddeti artıp azalmaz. Diğer nedenlere bağlı ağrılar ise; böbrek kapsülünün gerilmesi sonucunda oluşur (Ay ve ark. 2014).

Tedavi ve bakımda amaç, temel olarak ağrının etkili şekilde giderilip kontrol altına alınması ve üriner obstrüksiyonun renal işlev kaybına yol açmadan giderilmesini amaçlamaktadır (Ay ve ark. 2014). Hastaların kısa dönemde daha fazla analjezi gereksinimini azaltan NSAIII, akut renal kolikte opioid türevlerinden daha etkili analjeziklerdir (Türk ve ark. 2014). NSAIII'ın bağımlılık yapıcı etkileri, konstipasyon, solunum depresyonu, bilişsel değişiklikler gibi yan etkilerinin olmaması nedeniyle de daha fazla tercih edilen ajanlar olmuşlardır (Ay ve ark. 2014).

Nonsteroid anti-inflamatuar ilaçlar, lokal ödemi azaltarak inflamasyonu ve üreter düz kasların uyarılmasını, buna bağlı olarak da peristaltizmi ve üreterik basınç artışını önler. NSAIIİ kullanımı, renal kolikte ağrıyı azaltmanın yanında, renal kan akımını azaltarak böbreğin obstrüksiyona verdiği otoregülatuar yanıtı tersine çevirir. Analjezi tıbbi tedavi ile sağlanamazsa; drenaj, stent, perkütan nefrostomi veya taş kırma işlemi uygulanmalıdır (Ay ve ark. 2014; Türk ve ark. 2014).

Renal kolikte ağrı tedavisine yönelik öneriler Tablo 6'da yer almaktadır.

Tablo 6. Renal Kolikte Ağrı Tedavisine Yönelik Öneriler

\begin{tabular}{|l|c|}
\hline Öneriler & $\begin{array}{c}\text { Öneri } \\
\text { Düzeyi }\end{array}$ \\
\hline $\begin{array}{l}\text { Akut renal kolikte, analjezik tedaviye hemen } \\
\text { başlanılır. }\end{array}$ & $\mathrm{A}$ \\
\hline $\begin{array}{l}\text { Mümkünse bir NSAİİ ilk seçim olmalıdır. İlk } \\
\text { tercih; diklofenak, indometazin veya ibuprofen } \\
\text { vb. bir NSAİ் olmalıdır. }\end{array}$ & $\mathrm{A}$ \\
\hline $\begin{array}{l}\text { İkinci seçenek ise; hidromorfin, pentazosin } \\
\text { veya tramadoldur. }\end{array}$ & $\mathrm{C}$ \\
\hline $\begin{array}{l}\text { Tekrarlayan kolik tarzı ağrıyı azaltmak için } \\
\alpha \text {-blokerler kullanılır. }\end{array}$ & $\mathrm{A}$ \\
\hline
\end{tabular}

Kaynak: Türk, C. ve ark. (2014). Guidelines on urolithiasis. European Association of Urology, 16-17, http://uroweb.org/ wp-content/uploads/22-Urolithiasis_LR_full.pdf (10.08.2014).
A ğrı kontrolünde farmakolojik uygulamaların yanı sıra farmakolojik olmayan yöntemler de kullanılır;

- Periferal Tedaviler: Cilt uyarımı girişimleri sıcaksoğuk uygulamalar, egzersiz, pozisyon verme, hareket kısitlaması, dinlenme, akupunktur, hidroterapi, transkütanöz elektriksel sinir stimülasyonu (TENS), masaj ve dokunarak tedavi olarak siniflandırılır.

- Bilişsel Davranışçı Tedaviler: Gevşeme, dikkati başka yöne çekme, meditasyon, hipnoz, biyolojik geri bildirim, davranış tedavisi vb. yöntemleri içerir.

- Diğer Farmakolojik Olmayan Tedaviler ise; refleksoloji, aromaterapi ve müzik terapidir (Demir 2012; Kılıç ve Öztunç 2012; Yıldırım 2015).

Üroloji hastasının ağrı yönetiminde sıklıkla kullanılan farmakolojik olmayan yöntem, elektriksel sinir stimülasyonudur. Yüzeyel ve derin sinirlerin cilt yoluyla uyarılmasını içeren ve kronik ağrısı olan hastalarda sıklıkla kullanılan TENS'in interstisyel sistit/ ağrılı mesane sendromu olan hastalarda suprapubik ve vajinal-anal bölgelerine uygulanarak, ağrı düzeyini azalttığ 1 ; ancak posterior tibial sinir stimülasyonunun daha çok üriner semptomların azaltılmasında etkili olduğu çeşitli çalışmalarla gösterilmiştir (Ayyıldız ve ark. 2004; De Oliveira-Bernardes ve Bahamondes 2005; Gökyıldız-Bayrak ve Kızılkaya-Beji 2012; Özşaker ve Dramalı 2009; Schneider ve ark. 2013; Sikorski ve Barker 2009).

Literatür doğrultusunda, üroloji hastasının ağrı yönetiminde TENS'in etkinliği incelendiğinde; De OliveiraBernarde ve Bahamondes (2005)'in kronik pelvik ağrı sendromunun tedavisinde vajinal elektriksel stimülasyonun etkinliğini inceledikleri çalışmasında, tedavinin tamamlanmasindan 2 hafta, 4 hafta ve 7 ay sonra vajinal elektriksel stimülasyonun ağriyı azaltmada etkili oldu bulunmuştur $(\mathrm{p}<0.05)$. Schneider ve ark. (2013)'nın çalışmasında da, 12 hafta uygulanan TENS yönteminin ortalama görsel kıyaslama ölçeği (GKÖ) ağrı düzeyini 6.6'dan 3.9'a düşürdüğü saptanmıştır $(\mathrm{p}<0.001)$.

Göky1ldı-Bayrak ve Kızılkaya-Beji (2012)'nin kronik pelvik ağrısı olan kadınlarda posterior tibial elekt- 
riksel sinir stimülasyonunun (PTSS) yaşam kalitesi üzerine etkisini incelediği çalışmasında, PTSS öncesi deney grubundaki kadınların ortalama GKÖ ağrı düzeyinin $8.08 \pm 1.72$ iken; PTSS sonras1 ortalama GKÖ ağrı düzeyinin $2.62 \pm 2.70$ olduğu; tedavi öncesine göre tedavi sonrası ağrı düzeyinde istatistiksel olarak ileri düzeyde anlamlı bir fark olduğu saptanmıştır ( $\mathrm{p}=0.002$ ). Özşaker ve Dramalı (2009)'nın şok dalgaları ile taş kırma işleminde TENS'in ağrı üzerine etkisini incelediği bir başka çalışmada ise, TENS uygulanan hastalarda uygulanmayanlara göre ağrı puan1nın ve analjezik istek sayısının, HKA cihazının bolus olarak verdiği ilaç sayısının ve buna paralel olarak yan etki görülme sıklığının istatistiksel olarak anlamlı düzeyde düşük olduğu bulunmuştur $(\mathrm{p}<0.05)$.

Farmakolojik olmayan yöntemlerle ağrı kontrolüne ilişkin öneriler Tablo 7'de yer almaktadır.

Tablo 7. Farmakolojik Olmayan Yöntemlerle Ağrı Kontrolü

\begin{tabular}{|l|c|}
\hline Öneriler & $\begin{array}{c}\text { Öneri } \\
\text { Düzeyi }\end{array}$ \\
\hline $\begin{array}{l}\text { Farmakolojik olmayan yöntemlerle } \\
\text { farmakolojik yöntemlerin birlikte } \\
\text { kullanılması, etkili bir ağrı yönetimi sağlar. }\end{array}$ & $\mathrm{A}$ \\
\hline $\begin{array}{l}\text { Tedavide farmakolojik olmayan yöntemler, } \\
\text { farmakolojik yöntemlerin yerine } \\
\text { geçmemelidir. }\end{array}$ & $\mathrm{A}$ \\
\hline $\begin{array}{l}\text { Farmakolojik olmayan yöntemin seçiminde } \\
\text { bireyin tercihi temel alınmalıdır. }\end{array}$ & $\mathrm{A}$ \\
\hline $\begin{array}{l}\text { Eğitim ve psiko-eğitim girişimleri, ağrı } \\
\text { yönetiminde tedavinin bir parçasıdır. }\end{array}$ & $\mathrm{A}$ \\
\hline $\begin{array}{l}\text { Hasta ve ailesine eğitim verilmesi ve } \\
\text { psiko-sosyal girişimlerin uygulanması, } \\
\text { hasta ve ailesinin tedavi sürecine uyumunu } \\
\text { kolaylaştırır. }\end{array}$ & $\mathrm{A}$ \\
\hline
\end{tabular}

Kaynak: Eti-Aslan, F., Pamir-Aksoy, A. (2014). Ağrıda kanıta dayalı öneriler. Eti-Aslan (Ed.). A ğrı Doğası ve Kontrolü. Akademisyen Tıp Kitabevi, Ankara, 113-114.

\section{AĞRI KONTROLÜNDE HEMŞİRENIN ROLÜ}

Ağrıyı algılama, tanımlama ve ağrıya karşı ortaya çıkan davranışsal tepkiler, bireyden bireye değişiklik gösterir. Ağrının bireye özgü bir semptom olması, hastayı tüm yönleri ile tanıma ve doğru öykü almayı, sürekli gözlem yapmayı ve ağrı değerlendirmesinde uygun yöntemleri kullanmayı gerektirir (Eti-Aslan ve Kan-Öntürk 2014).

Hemşire, ağriya yönelik girişimlerini planlarken, ayrıntılı bir anamnez almalıdır. Ağrı ile ilgili anamnez alırken; ağrının şiddeti, yeri, niteliği, başlangıcı, süresi, ağrıyı arttıran ve azaltan özellikler dikkatlice sorgulanmalıdır (Pirbudak-Çöçelli, Bacaksız ve Ovayolu 2008; Sikorski ve Barker 2009; Y1ldırım 2015).

İnsan yaşamında çok fazla olumsuz etkileri olan ağrının ortak bir dil kullanılarak ölçülebilmesi; ağrının kendisi ve uygulanan ağrı giderme yöntemlerinin etkinliğinin değerlendirilmesi açısından önemlidir (Eti-Aslan ve Kan-Öntürk 2014; Yıldırım 2015). Ağrı değerlendirmesinde kullanılan ölçekler, ağrıyı tek boyutlu değerlendiren ölçekler ve çok boyutlu değerlendiren ölçekler olmak üzere ikiye ayrılır.

Tek Boyutlu Ölçekler: Ağrıyı tek boyutlu değerlendiren ölçekler, ağrı şiddeti gibi spesifik bir parametre üzerine odaklanır ve ağrı deneyiminin sadece bir boyutunu değerlendirir. Sayısal ölçekler, Sözel Kategori Ölçeği, Vizüel Analog Skalası (VAS) ve Burford Ağrı Termometresi ağrıyı tek boyutlu değerlendiren ölçeklerdir (Pirbudak-Çöçelli ve ark. 2008; Yıldırım 2015).

Çok Boyutlu Ölçekler: Ağrıyı tanımlayıcı ifadelerin yer aldığı, daha geniş kapsamlı hazırlanmış ölçeklerdir. Çok boyutlu yöntemler, ağrının şiddeti yanında diğer boyutların da ölçülmesine olanak sağladığı için ağrı değerlendirme yöntemleri olarak da kabul edilmektedir (Eti-Aslan ve Kan-Öntürk 2014; PirbudakÇöçelli ve ark. 2008).

Ağrı şiddetini ve hastaya uygulanan girişimlerin etkinliğini saptamak için sürekli ağrn değerlendirilmesi önemlidir. Ağrının özelliğinde bir değişiklik olması durumunda veya hasta yeni bir ağn yeri bildirdiğinde, ayrıntılı değerlendirmenin yapılması gereklidir ve yapılan tüm değerlendirmeler kayıt edilmelidir (Yıldırım 2015).

\section{A ğrılı hastaya bakım verirken;}

- Hastaya bütüncül yaklaşımla bakım verilmesi,

- Nedeni ne olursa olsun ağrının bir "yardım arayışı" olduğunun unutulmaması, 
- Ağrının kaynağının bulunmaya çalışılması ve tedavi için uygun önlemler alınması,

- Ağrının artmasına neden olan durumların giderilmesi,

- Hastanın daha önce ağrısını gidermeye yönelik kullandığı yöntemlerin sorulması,

- Öncelikle etkinliği kanıtlanan farmakolojik olmayan yöntemlerin tercih edilmesi,

- Hekim istemine uygun analjeziklerin uygulanması ve yan etkilerinin gözlenmesi,

- Hasta yakınlarının bakıma katılmasının sağlanması,

- Hemşirenin, hastanın ağrısını gidermek ve en aza indirebilmek için uygun yöntemleri hasta ile birlikte seçmesi ve uygulaması,

- Farmakolojik olmayan yaklaşımların, her zaman ağrı yönetiminin bir parçası oluğunun unutulmaması,

- Hastanın bilgi eksikliklerinin saptanması ve eğitim planlanmasi,

- Hasta ve hasta yakınlarının ağrıya ilişkin yanlış inançları varsa, saptanması ve düzeltilmeye çalışılması,

- Hemşirenin, hastanın ağrısını gidermede uygulanacak olan yöntemlerle ilgili hastayı hazırlaması, yöntemin ağrıyı gidermedeki etkisini ve nasıl uygulanacağıyla ilgili açıklama yapması, önerilmektedir (Kılıç ve Öztunç 2012; Yıldırım 2015).

Oldukça karmaşık ve çok boyutlu bir deneyim olan ağr1, bireyin yaşam kalitesini olumsuz yönde etkileyen önemli bir sağlık sorunudur. Ağrı yönetimine yönelik sürekli elde edilen yeni bilgiler, sağlık profesyonellerinin hasta için en iyi ve en doğru olan yöntemi seçebilmesini gerektirmektedir. Kanıta dayalı klinik uygulama rehberlerinin izlemi bu amaca ulaşmada anahtar rol oynamaktadır (Eti-Aslan ve Pamir-Aksoy 2014).

\section{SONUÇ VE ÖNERILER}

Sonuç olarak; ekibin etkin bir üyesi olarak çalışan üroloji hemşirelerinin, ağn kontrol yöntemleri içerisinde yer alan farmakolojik ve farmakolojik olmayan yöntemlere ilişkin bilgilendirilmeleri, hemşirelerin öncelikle etkinliği kanitlanan farmakolojik olmayan yöntemleri tercih etmeleri ve bu konuda yapılan çalışmalara katılarak literatürdeki eksikliğin giderilmesine katkıda bulunmaları.

\section{KAYNAKLAR}

Anothaisintawee, T. ve ark. (2011). Management of chronic prostatitis/ chronic pelvic pain syndrome: A systematic review and network meta-analysis. JAMA, 305(1): 78-86.

Atan, A., Tuncel, A. (2013). Erkek genitüriner sistem cerrahilerinden sonra oluşan ağrının mekanizması ve tedavi yaklaşımları. Yeni Üroloji Derg., 8(1): 72-76.

Atuğ, F., Canoruç, N. (2005). İnterstisyel sistit: Kronik pelvik ağrı sendromu. Dicle Tip Derg., 32(4): 204-210.

Ay, M. O. ve ark. (2014). Acil serviste renal kolikli hasta yönetimi. ARŞİ , 23(2): 345-361.

Ayyıldız, A. ve ark. (2004). Ekstrakorporal şok dalgası ile taşın kırılması (ESWL) esnasında oluşan ağrının azaltılması amacıyla transkutanöz elektrik sinir stimülasyonu (TENS) uygulanması. Turk Urol Derg., 30(4): 446-450.

Burke, K. M., Mohn-Brown, E. L., Eby, L. (Eds.) (2011). Caring for clients with renal and urinary tract disorders. Medical-Surgical Nursing Care. 3rd ed., Pearson Education, New Jersey, 758-765.

Chaiken, D. C., Blaivas, J. G., Blaivas, S. T. (1993). Behavioral therapy for the treatment of refractory interstitial cystitis. J Urol., 149(6): 1445-1448.

Çakıroğlu, Ç. ve ark. (2013). Renal kolikli hastalarda bilgisayarlı tomografi ile ultrasonagrafi bulgularının karşılaştırılması. JAREM, 2013(3): 31-35.

De Oliveira-Bernardes, N., Bahamondes, L. (2005). Intravaginal electrical stimulation for the treatment of chronic pelvic pain. $J$ Reprod Med., 50(4): 267-272.

Demir, Y. (2012). Non-pharmacoogical terapies in pain management. INTECH Open Access Publisher, 485-503, http://www.intechopen.com/download/pdf/26152 (12.08.2014).

Elist, J. (2006). Effects of pollen extract preparation prostat/ poltit on lower urinary tract symptoms in patients with chronic nonbacterial prostatitis/ chronic pelvic pain syndrome: A randomized, double-blind, placebocontrolled study. Urology, 67(1): 60-63.

Engeler, D. ve ark. (2014). Guidelines on chronic pelvic pain. European Association of Urology, 27-75, https://uroweb.org/wpcontent/uploads/26-Chronic-Pelvic-Pain_LR.pdf (10.08.2014).

Erdil, F. (2008). Ürogenital sistem cerrahisi. Erdil, F., Özhan-Elbaş, N. (Eds.). Cerrahi Hastalıkları Hemşireliği. Aydoğdu Ofset Matbaacılık Ambalaj Sanayi ve Tic. Ltd. Şti., Ankara, 377-378.

Eti-Aslan, F., Kan-Öntürk, Z. (2014). Ağrı ölçümü ve değerlendirilmesi. Eti-Aslan, F. (Ed.). A ̆grı Doğası ve Kontrolü. Akademisyen Tip Kitabevi, Ankara, 67-100.

Eti-Aslan, F., Pamir-Aksoy, A. (2014). Ağrıda kanıta dayalı öneriler. Eti-Aslan, F. (Ed.). A $\breve{g r ı ~ D o g ̆ a s ı ~ v e ~ K o n t r o l u ̈ . ~ A k a d e m i s y e n ~ T ı p ~}$ Kitabevi, Ankara, 113-114. 


\section{Üroloji Hastasında Ağrı Yönetimi: Güncel Yaklaşımlar ve Kanıta Dayalı Uygulamalar}

Foster, H. E. ve ark. (2010). Effect of amitriptyline on symptoms in treatment naive patients with interstitial cystitis/ painful bladder syndrome. J Urol., 183(5): 1853-1858.

Frizelle, H. (2006). Mechanisms of postoperative pain-nociceptive. Shorten, G., Carr, D. B., Harmon, D., Puig, M. M., Browne, J. (Eds.). Postoperative Pain Management. Saunders Elsevier, Philadelphia, 34-39.

Gökyıldız, Ş., Kızılkaya-Beji, N. (2012). Chronic pelvic pain: Gynaecological and non-gynaecological causes and considerations for nursing care. Int J Urol Nurs., 6(1): 3-10.

Hansen, H. C. (2000). Interstitial cystitis and the potential role of gabapentin. South Med J., 93(2): 238-242.

Karaca, A., Yeşiltepe-Kaçar, G. (2013). Üriner sistem hastalıkları ve bakım. Durna, Z. (Ed.). İç Hastalıkları Hemşireliği. Akademi Basın ve Yayıncılık, İstanbul, 450-451.

Kılıç, M., Öztunç, G. (2012). Ağrı kontrolünde kullanılan yöntemler ve hemşirenin rolü. Firat Sağllk Hizmetleri Derg., 7(21): $35-51$.

Özbaş, A., Altun-Uğraş, G. (2012). İntertisiyel sistit/ ağrılı mesane sendromunda semptom yönetimi ve hemşirenin rolü. F. N. Hem Derg., 20(3): 227-232.

Özşaker, E., Dramalı, A. (2009). Şok dalgaları ile taş kırma işleminde TENS'in ağrıyı gidermedeki etkisinin incelenmesi. Ege Üniversitesi Hemşirelik Yüksekokulu Derg., 25(3): 37-53.

Paez-Borda, A., Charnay-Sonnek, F., Fonteyne, V., Papaioannou, E. G. (2014). Guidelines on pain management \& palliative care. European Association of Urology, 30-37, https://uroweb.org/wpcontent/uploads/25-Pain-Management_LR.pdf (10.08.2014).
Parsons, C. L., Koprowski, P. F. (1991). Interstitial cystitis: Successful management by increasing urinary voiding intervals. Uro$\log y, 37(3):$ 207-212.

Pirbudak-Çöçelli, L., Bacaksız, B. D., Ovayolu, N. (2008). Ağrı tedavisinde hemşirenin rolü. Gaziantep Tip Derg., 14(2): 53-58.

Sasaki, K. ve ark. (2001). Oral gabapentin (neurontin) treatment of refractory genitourinary tract pain. Tech Urol., 7(1): 47-49.

Schneider, M. P. ve ark. (2013). Refractory chronic pelvic pain syndrome in men: Can transcutaneous electrical nerve stimulation help? BJU International, 112(2): 159-163.

Sikorski, K. A., Barker, D. M. (2009). Clients with pain. Black, J. M., Hawks, J. H. (Eds.). Medical-Surgical Nursing Clinical Management for Positive Outomes. Saunders, St. Louis, 351-384.

Türk, C. ve ark. (2014). Guidelines on urolithiasis. European Association of Urology, 16-17, http://uroweb.org/wp-content/uploads/22Urolithiasis_LR_full.pdf (10.08.2014).

Van Ophoven, A., Pokupic, S., Heinecke, A., Hertle, L. (2004). A prospective, randomized, placebo controlled, double-blind study of amitriptyline for the treatment of interstitial cystitis. $J$ Urol., 172(2): 533-536.

Van Ophoven, A., Hertle, L. (2005). Long-term results of amitriptyline treatment for interstitial cystitis. J Urol., 174(5): 1837-1840.

Wagenlehner, F. M. ve ark. (2009). A pollen extract (Cernilton) in patients with inflammatory chronic prostatitis-chronic pelvic pain syndrome. Eur Urol., 56(3): 544-551.

Yıldırım, Y. (2015). Kanser ağrısı. Can, G. (Ed.). Onkoloji Hemşireliği. Nobel Tıp Kitabevleri, İstanbul, 317-333. 
